\title{
Endophyte-Mediated Suppression of Dollar Spot Disease in Fine Fescues
}

\author{
Bruce B. Clarke, Professor, James F. White, Jr., Professor, and Richard H. Hurley, Adjunct Professor, Mónica S. \\ Torres, Research Assistant, Department of Plant Biology \& Pathology, Rutgers University, New Brunswick, NJ \\ 08903; S. Sun, Scientist, Turf-Seed, Inc., 23014 Settler Drive, Liberty Lake, WA 99019; and David R. Huff, Profes- \\ sor, Department of Agronomy, Pennsylvania State University, University Park 16802
}

\begin{abstract}
Clarke, B. B., White, J. F., Jr., Hurley, R. H., Torres, M. S., Sun, S., and Huff, D. R. 2006. Endophyte-mediated suppression of dollar spot disease in fine fescues. Plant Dis. 90:994-998.

In 1989, a close association was found between single-plant progenies of strong creeping red fescue infected with the endophyte Epichloë festucae and enhanced suppression of dollar spot, a widespread foliar disease of turfgrass caused by Sclerotinia homoeocarpa. From this limited observation, extensive field evaluations were conducted on a wide range of fine fescue germplasm obtained throughout the United States and Europe to determine the frequency and magnitude of this association. In five field trials established between 1985 and 1991, endophyteinfected Chewings, hard, blue, and strong creeping red fescue cultivars, selections, and crosses consistently exhibited endophyte-mediated suppression of dollar spot, when compared with closely related endophyte-free entries. Endophyte-infected Chewings and hard fescue cultivars and selections also had greater turf density and supported less foliar mycelium of $S$. homoeocarpa than endophyte-free entries.
\end{abstract}

Additional keywords: defensive mutualism, Neotyphodium, symbiosis

Many grasses contain endophytic fungi classified in the genera Epichloë and Neotyphodium of the ascomycete family Clavicipitaceae $(14,16,22)$. Endophytes in tall fescue (Festuca arundinacea) and perennial ryegrass (Lolium perenne) are responsible for causing toxic syndromes in cattle, sheep, and horses $(10,16)$. Because of the toxicosis that develops in animals that consume endophyte-infected forage grasses, endophytes are often considered a liability in forage species. It has become clear, however, that endophytes may also confer benefits in grasses that include insect resistance $(3,4,9)$ and increased drought tolerance (21). This has made the use of endophytes in turfgrass species an attractive alternative to external inputs used to enhance turfgrass performance $(5,6,18)$.

Early cultural studies on endophytes have demonstrated that several endophytes produce compounds that inhibit a range of fungal pathogens of grasses $(14,15,23)$. Tajimi (19) demonstrated that endophyteinfected timothy (Phleum pratense) in a

Corresponding author: J. F. White, Jr.

E-mail: jwhite@aesop.rutgers.edu

Accepted for publication 14 February 2006.

DOI: 10.1094/PD-90-0994

(C) 2006 The American Phytopathological Society spaced-plant nursery showed less leaf spot disease caused by Cladosporium phlei and stem rust caused by Puccinia graminis when compared with endophyte-free plants. Greulich et al. (7) showed field protection of timothy from $C$. phle $i$ when infected by the endophyte Epichloe typhina. Researchers at the University of Tennessee $(1,8)$ demonstrated that endophyte-infected tall fescue seedlings had reduced disease caused by Rhizoctonia zeae in laboratory and greenhouse studies. However, another study by Welty et al. (20) reported no effects of endophytic infection by Neotyphodium coenophialum on the susceptibility of tall fescue to rust caused by $P$. graminis.

We conducted research on the possible association between endophyte infection of fine fescues and resistance to fungal diseases. In 1989, several single-plant progenies tracing their maternal origin to a strong creeping red fescue plant (Festuca rubra subsp. rubra) collected from the Rose City Cemetery in Portland, OR, showed good field resistance to dollar spot, a widespread foliar disease of turfgrasses caused by Sclerotinia homoeocarpa. This observation was made at the Rutgers Plant Science Research Farm in Adelphia, NJ, and was considered important because, as a group, strong creeping red fescues are generally considered to be very susceptible to dollar spot (17). Upon verifying the endophyte status of these progenies, a close association was found between plants infected with Epichloë festucae and reduced dollar spot disease. From these limited observations, more extensive field evaluations were conducted on a wide range of fine fescue germplasm obtained from throughout the United States and Europe to determine the frequency of this association.

\section{MATERIALS AND METHODS}

This study was conducted on fine fescue turfgrass evaluation trials established in 1985, 1988, 1989, 1990, and 1991 at the Rutgers Plant Science Research Farm, Adelphia, NJ. Each cultivar or selection was seeded by hand in the fall of the year at a rate of $133.7 \mathrm{~kg} \mathrm{ha}^{-1}$. Plots were $1.1 \times$ $1.7 \mathrm{~m}$ and were replicated at least three times in a randomized block design. The 1985 trial was maintained at a $5.1-\mathrm{cm}$ mowing height and moderate fertility (107.8 kg N ha ${ }^{-1}$ year $^{-1}$ ) until 1989, when fertilizer applications were discontinued. The trials established in 1988 and 1989 were maintained at a height of $4.2 \mathrm{~cm}$ and moderate/high fertility $\left(107.8 \mathrm{~kg} \mathrm{~N} \mathrm{ha}{ }^{-1}\right.$ year $^{-1}$ and $151.9 \mathrm{~kg} \mathrm{~N}^{-1}$ year $^{-1}$, respectively) throughout the study. The 1991 trial received $117.6 \mathrm{~kg} \mathrm{~N}^{-1}$ year $^{-1}$, except in 1992, when the trial received $58.8 \mathrm{~kg} \mathrm{~N}^{-1}$ from 15 April to 1 September. In the fall of 1992, plots were equally split into high and low fertility subplots, and the high fertility half of each plot received an additional 46.5 $\mathrm{kg} \mathrm{N} \mathrm{ha}^{-1}$ on 2 September and 21 September 1992, respectively. Turf in this trial was maintained at a $3.8-\mathrm{cm}$ mowing height. The test area consisted of a sandy loam soil. Soil $\mathrm{pH}$ ranged from 5.7 to 6.5 . Irrigation was applied during the growing season to prevent severe drought stress. No insecticides or fungicides were used.

The endophyte status of each fine fescue cultivar, selection, or cross was determined microscopically by examining leaf sheaths of 10 randomly selected tillers per entry using the rose bengal staining method described by Saha et al. (12,13). Dollar spot severity was assessed by direct visual estimation of the proportion of foliar area showing necrosis induced by natural infestations of $S$. homoeocarpa to the nearest $1 \%(0-100 \%)$. The pathogen was isolated at each rating date on potato dextrose agar 
(Difco Laboratories, Detroit, MI), and its identity was confirmed microscopically and serologically through the use of immunoassays (Neogen Corp., East Lansing, MI). Turf density was determined by visually estimating the percentage of living grass swards per plot. Turf quality was assessed several times each year on a 1 to 9 scale, where 1 was poorest and 9 was equal to the best-quality turf. This assessment was based on many factors including texture, plant density, color, and damage caused by diseases. Each test was evaluated by two or more individuals to reduce subjective bias. Data were subjected to an arcsine transformation for better approximation to normal distribution prior to statistical analysis by ANOVA and the least significant difference (LSD) multiple comparisons test $(P=0.05)$.

\section{RESULTS}

In a 1985 Chewings and hard fescue field trial, an endophyte-infected (E+) Chewings fescue (F. rubra subsp. fallax) cultivar Longfellow and the progenies of six of its crosses, together with an E+ hard fescue (F. brevipila) cultivar SR 3000 and the progenies of seven crosses with a similar hard fescue, showed significantly higher resistance to dollar spot in comparison with related endophyte-free (E-) entries (Table 1). The average percent turf areas exhibiting dollar spot symptoms for E+ and E- entries were 4.9 and $44.1 \%$, respectively. The E+ entries also had a higher turf density than the E- entries, $98.4 \%$ compared with $31.4 \%$, respectively. In the 1988 seeding of strong creeping red fescue, four selections showed significantly less damage from dollar spot disease compared with other strong creeping red fescue entries (Table 2, Fig. 1). One of these selections, Rose City, contained the endophytic fungus E. festucae originating from a single plant of strong creeping red fescue collected from the Rose City Cemetery, Portland, OR. The other three dollar spot resistant selections contained endophytes of the same species obtained from 'Ensylva' strong creeping red fescue and a single strong creeping red fescue plant discovered in a plot of 'Kenblue' Kentucky bluegrass seeded at Adelphia. In a 1989

Table 1. Turf density and disease severity of endophyte-infected and endophyte-free Chewings and hard fescue cultivars, selections, and crosses to dollar spot in a field trial established September 1985 at Adelphia, NJ

\begin{tabular}{|c|c|c|c|c|}
\hline \multirow[b]{2}{*}{ Entry $^{w}$} & \multirow[b]{2}{*}{ Endophyte $^{x}$} & \multirow{2}{*}{$\frac{\text { Turf density }^{\mathrm{u}}}{1991}$} & \multicolumn{2}{|c|}{ Disease severity $^{v}$} \\
\hline & & & 1991 & 1992 \\
\hline \multicolumn{5}{|l|}{ Chewings fescue } \\
\hline Longfellow & E+ & 98.5 & 5.7 & 2.0 \\
\hline Longfellow 10 & E- & 27.0 & 54.2 & 70.5 \\
\hline $\operatorname{LSD}(P=0.05)$ & & 5.6 & 9.1 & 8.1 \\
\hline Longfellow $\times$ Waldorf & $\mathrm{E}+$ & 99.3 & 5.8 & 1.0 \\
\hline Longfellow $\times$ Longfellow $1 \mathrm{OBC} 1^{z}$ & $\mathrm{E}+$ & 97.7 & 6.5 & 1.2 \\
\hline Longfellow $\times$ Longfellow 10 & $E+$ & 96.7 & 6.2 & 1.2 \\
\hline Longfellow $\times$ Jamestown & $\mathrm{E}+$ & 95.8 & 7.1 & 1.2 \\
\hline Longfellow $\times$ Shadow & $E+$ & 98.3 & 7.0 & 1.7 \\
\hline Longfellow $\times$ Banner & E+ & 95.3 & 9.5 & 1.8 \\
\hline Shadow & E- & 21.7 & 38.8 & 16.7 \\
\hline Jamestown & E- & 21.7 & 41.3 & 45.7 \\
\hline $\operatorname{LSD}(P=0.05)$ & & 4.7 & 6.7 & 13.6 \\
\hline \multicolumn{5}{|l|}{ Hard fescue } \\
\hline SR 3000 & $\mathrm{E}+$ & 98.7 & 5.6 & 1.8 \\
\hline SR 3000 & E- & 26.7 & 56.8 & 18.2 \\
\hline $\operatorname{LSD}(P=0.05)$ & & 3.7 & 7.7 & 2.8 \\
\hline ST & $\mathrm{E}+$ & 98.8 & 3.8 & 1.0 \\
\hline ST $\times$ Reliant & $E+$ & 98.0 & 5.1 & 1.0 \\
\hline ST $\times$ Aurora & $\mathrm{E}+$ & 100.0 & 1.8 & 1.3 \\
\hline ST $\times$ Spartan & $\mathrm{E}+$ & 99.3 & 2.9 & 1.5 \\
\hline ST $\times$ Waldina & $\mathrm{E}+$ & 98.3 & 2.9 & 1.5 \\
\hline $\mathrm{ST} \times \mathrm{TRMR}$ & E+ & 98.5 & 4.5 & 2.8 \\
\hline TRMR & E- & 45.0 & 29.2 & 11.0 \\
\hline Reliant & E- & 29.0 & 48.5 & 17.1 \\
\hline Spartan & E- & 31.3 & 38.2 & 18.5 \\
\hline Aurora & E- & 30.0 & 48.5 & 21.4 \\
\hline ST & E- & 40.0 & 40.6 & 25.3 \\
\hline $\operatorname{LSD}(P=0.05)$ & & 10.6 & 12.9 & 12.0 \\
\hline \multicolumn{5}{|c|}{$\begin{array}{l}\text { u Turf density was determined on } 3 \text { October } 1991 \text { by visually estimating the percentage of living turf per } 1.1 \\
\times 1.7 \mathrm{~m} \text { plot. }\end{array}$} \\
\hline \multicolumn{5}{|c|}{$\begin{array}{l}{ }^{\mathrm{V}} \text { Disease severity was assessed as the percent turf area exhibiting foliar symptoms of dollar spot. Values are } \\
\text { means of two and three evaluations made during the } 1991 \text { and } 1992 \text { growing seasons, respectively. }\end{array}$} \\
\hline \multicolumn{5}{|c|}{$\begin{array}{l}\text { w Entries were replicated three times except for cultivars Longfellow (E+) and SR } 3000 \text { (E+), which were } \\
\text { replicated } 15 \text { and } 12 \text { times, respectively. }\end{array}$} \\
\hline \multirow{2}{*}{\multicolumn{5}{|c|}{$\begin{array}{l}\text { Endophyte status was determined microscopically by examining the leaf sheaths of } 10 \text { randomly selected } \\
\text { tillers per entry stained with rose bengal. Endophyte-infected and endophyte-free entries are represented by } \\
\text { E+ and E-, respectively. }\end{array}$}} \\
\hline & & & & \\
\hline${ }^{\mathrm{y}}$ The first component of each cross in th & thle was the $F$ & & & \\
\hline
\end{tabular}

seeding, which contained 12 each of the $\mathrm{E}+$ and E- selections of strong creeping red fescue, the differences in dollar spot susceptibility were striking. The E- plots showed an average of $61.5 \%$ turf area damaged by dollar spot, whereas E+ plots showed only $0.3 \%$ of the turf area infected (data not shown). In the 1990 field trial, E+ plots of blue fescue (F. ovina), Chewings fescue, hard fescue, and strong creeping red fescue showed significantly less dollar spot than E- plots (Table 3). When comparing only E- germplasm, strong creeping red fescue cultivars and selections were consistently more susceptible to dollar spot than were the Chewings, blue, or hard fescue entries.

In a 1991 seeding of Chewings and hard fescue cultivars, E+ plots again demonstrated less dollar spot than E- plots (Table 4). E- entries had more foliar mycelium of S. homoeocarpa than E+ entries, $8.0 \%$ versus $0.5 \%$, respectively. When turf was evaluated for disease on 7 October 1992 , the half of each plot receiving higher nitrogen fertility $\left(105.3 \mathrm{~kg} \mathrm{~N} \mathrm{ha}^{-1}\right.$ year $\left.^{-1}\right)$ sustained consistently less dollar spot than the low nitrogen fertility $\left(58.8 \mathrm{~kg} \mathrm{~N} \mathrm{ha}^{-1}\right.$ year $^{-1}$ ) half. Within each fertility treatment, E- entries were more susceptible to dollar spot than E+ entries.

Table 2. Disease severity of endophyte-infected and endophyte-free strong creeping red fescue cultivars and selections to dollar spot in a field trial established September 1988 at Adelphia, NJ

\begin{tabular}{lcc}
\hline Entry & Endophyte & $\begin{array}{c}\text { Disease } \\
\text { severity }(\boldsymbol{\%})^{\mathbf{z}}\end{array}$ \\
\hline Rose City & E+ & 2.0 \\
PST 43E & E+ & 3.0 \\
PST 4DD & E- & 3.7 \\
PST 4CR & E- & 5.3 \\
VDH-7 & E- & 20.0 \\
VDH-6 & E- & 21.3 \\
VDH-5 & E- & 21.3 \\
VDH-4 & E- & 21.8 \\
VDH-3 & E- & 22.5 \\
PST 4RD & E- & 23.3 \\
PST 43F & E- & 25.7 \\
PST 4RE & E- & 25.7 \\
VDH-2 & E- & 26.3 \\
Shademaster & E- & 26.7 \\
GS-551 & E- & 30.0 \\
PST 43E & E- & 35.0 \\
PST 4C8 & E- & 35.0 \\
PST 4NI & E- & 35.0 \\
VDH-1 & E- & 37.5 \\
ZPS 5101 & E- & 42.5 \\
LSRS & E- & 50.0 \\
DS-88 & E- & 53.3 \\
GW-87 & E- & 55.0 \\
LSD $(P=0.05)$ & & 14.1 \\
\hline
\end{tabular}

${ }^{y}$ Endophyte status was determined microscopically by examining the leaf sheaths of 10 randomly selected tillers per entry stained with rose bengal. Endophyte-infected and endophyte-free entries are represented by E+ and E-, respectively.

${ }^{\mathrm{z}}$ Disease severity was assessed as the percent turf area exhibiting foliar symptoms of dollar spot. Values are means of three replicates evaluated on 5 September 1991. 


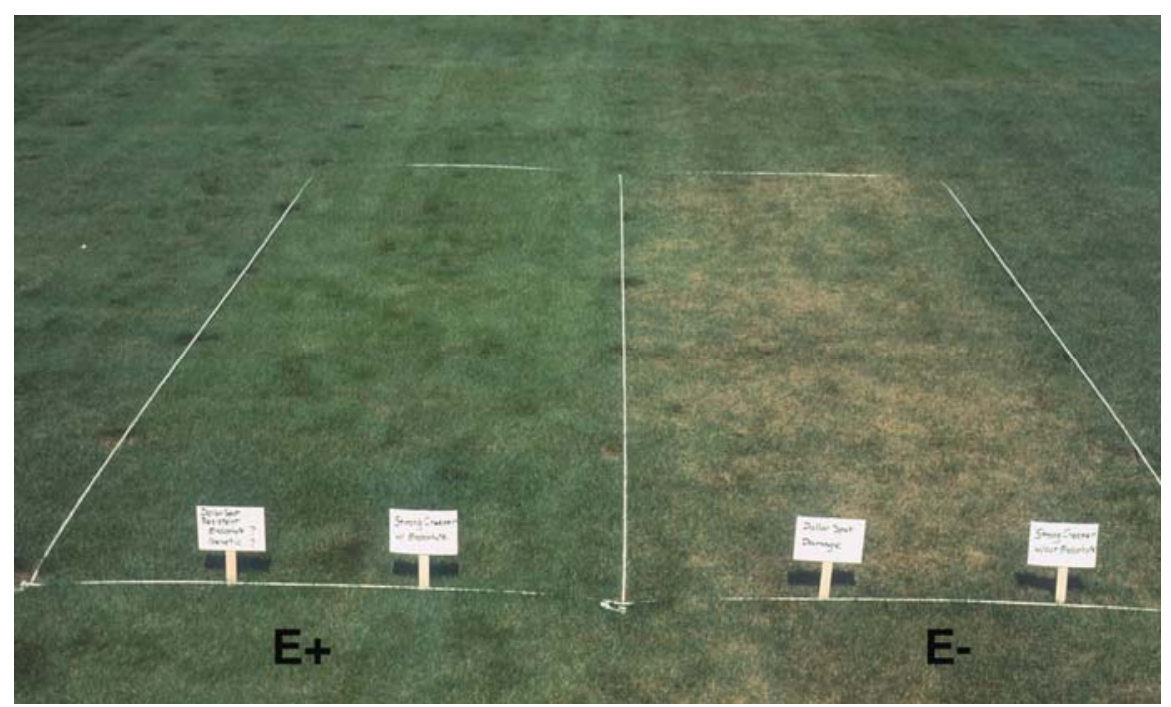

Fig. 1. Strong creeping red fescue selections with and without endophyte. Endophyte-free plot on right shows substantial damage due to dollar spot, whereas endophyte-containing selection on left shows minimal dollar spot damage.

Table 3. Turf quality and disease severity in blue, Chewings, hard, and strong creeping red fescue cultivars and selections (with and without endophyte) established September 1990 in a field trial at Adelphia, NJ

\begin{tabular}{|c|c|c|c|c|c|c|c|}
\hline \multirow[b]{3}{*}{ Entry ${ }^{z}$} & \multirow[b]{3}{*}{ Endophyte ${ }^{z}$} & \multirow{2}{*}{\multicolumn{3}{|c|}{ Turf quality $^{\mathbf{y}}$}} & \multicolumn{3}{|c|}{ Disease severity $^{x}$} \\
\hline & & & & & \multirow{2}{*}{$\begin{array}{l}7-24 \\
1992\end{array}$} & \multirow{2}{*}{$\begin{array}{c}10-8 \\
1992\end{array}$} & \multirow{2}{*}{$\begin{array}{l}9-17 \\
1993\end{array}$} \\
\hline & & 1991 & 1992 & 1993 & & & \\
\hline \multicolumn{8}{|l|}{ Blue fescue } \\
\hline SR 3200 & $\mathrm{E}+$ & 5.4 & 5.7 & 4.9 & 1.7 & 8.7 & 16.7 \\
\hline SRX 3210 & $\mathrm{E}+$ & 5.3 & 5.4 & 4.5 & 0.0 & 6.7 & 21.3 \\
\hline SR 3200 & E- & 5.2 & 5.1 & 4.5 & 1.7 & 51.7 & 32.3 \\
\hline SRX 3210 & E- & 4.7 & 4.3 & 4.4 & 1.7 & 46.7 & 45.0 \\
\hline \multicolumn{8}{|l|}{ Chewings fescue } \\
\hline SR 5100 & $\mathrm{E}+$ & 6.4 & 6.5 & 6.4 & 0.0 & 1.3 & 7.0 \\
\hline Banner II & $\mathrm{E}+$ & 5.6 & 6.0 & 4.9 & 0.0 & 1.0 & 9.3 \\
\hline Jamestown II & $\mathrm{E}+$ & 5.6 & 5.9 & 5.3 & 0.0 & 1.0 & 13.7 \\
\hline Banner & E- & 5.0 & 5.0 & 5.1 & 0.0 & 10.0 & 16.7 \\
\hline Jamestown & E- & 4.7 & 4.9 & 4.7 & 0.0 & 14.7 & 27.0 \\
\hline SR 5100 & E- & 6.6 & 6.9 & 6.1 & 1.7 & 5.3 & 27.7 \\
\hline Longfellow & E- & 5.6 & 5.7 & 5.2 & 0.0 & 44.3 & 41.3 \\
\hline \multicolumn{8}{|l|}{ Hard fescue } \\
\hline 4HD-90 PST & $\mathrm{E}+$ & 6.2 & 6.5 & 5.9 & 0.0 & 2.7 & 7.0 \\
\hline Nordic & E- & 6.0 & 6.1 & 6.0 & 1.7 & 23.3 & 32.3 \\
\hline Reliant & E- & 5.4 & 5.8 & 5.0 & 0.0 & 30.0 & 40.3 \\
\hline Aurora & E- & 5.2 & 5.2 & 4.8 & 3.3 & 38.3 & 54.0 \\
\hline \multicolumn{8}{|c|}{ Strong creeping red fescue } \\
\hline Syn 4SS & E+ & 5.7 & 5.2 & 5.6 & 3.3 & 1.7 & 11.3 \\
\hline 4R3-90 PST & E+ & 5.5 & 5.4 & 4.9 & 1.7 & 8.0 & 13.7 \\
\hline Boreal & E- & 3.3 & 3.7 & 2.9 & 32.0 & 75.0 & 53.7 \\
\hline Salem & E- & 3.7 & 3.0 & 3.3 & 88.0 & 75.0 & 59.0 \\
\hline Jasper & E- & 4.4 & 4.5 & 3.3 & 92.0 & 61.7 & 63.3 \\
\hline Vista & E- & 3.9 & 3.7 & 3.1 & 92.0 & 73.3 & 68.0 \\
\hline Flyer & E- & 3.8 & 3.8 & 3.0 & 95.0 & 51.7 & 73.0 \\
\hline Shademaster & E- & 3.8 & 3.7 & 3.2 & 97.0 & 58.3 & 83.0 \\
\hline $\operatorname{LSD}(P=0.05)$ & & 0.6 & 1.1 & 0.7 & 16.3 & 24.1 & 18.4 \\
\hline
\end{tabular}

${ }^{x}$ Disease severity was assessed as the percent turf area exhibiting foliar symptoms of dollar spot. Values are means of two and three evaluations made during the 1992 and 1993 growing seasons, respectively. Entries were replicated three times.

y Turf quality was determined using a visual rating scale of 1 to 9 , where 9 is the best quality turf. Values are annual means of multiple evaluations conducted throughout the 1991, 1992, and 1993 growing seasons.

${ }^{\mathrm{z}}$ Endophyte status was determined microscopically by examining the leaf sheaths of 10 randomly selected tillers per entry stained with rose bengal. Endophyte-infected and endophyte-free entries are represented by E+ and E-, respectively.
The average annual turf quality ratings for E+ and E- cultivars and selections for all trials in the study were similar until 1991, when substantial damage from dollar greater than those of E- entries. However, turf quality ratings for $\mathrm{E}+$ and $\mathrm{E}$ - cultivars and selections of blue and Chewings fescues during this period were generally similar.

\section{DISCUSSION}

Dollar spot is an important disease of both cool- and warm-season turf. Infections are typically initiated in late spring, summer, and autumn. Once infection foci are established, they are persistent and the disease may redevelop at those sites season after season. Dollar spot is usually controlled with the use of nitrogen fertilizers and fungicide applications throughout the growing season (17). The discovery in the current study that endophytes provide a high degree of suppression of dollar spot in several fine fescue species is important, since the cost of controlling this disease could be reduced considerably through use of endophyte-infected turf. A recent study by Bonos et al. (2) has shown that endophytes in fine fescues increase resistance to red thread disease caused by Laetisaria fuciformis. Previous laboratory and greenhouse studies have suggested the potential for enhanced disease resistance in endophyte-infected grasses $(8,19,23)$. Our findings of suppression of dollar spot disease and the results indicating resistance to red thread disease show the potential of endophytes as a strategy for controlling fungus diseases in turfgrasses under field conditions.

The benefits associated with endophytes in grasses are frequently observed only when grasses are grown under certain biological and/or environmental stresses. Intensive cultivation, mowing, low fertility, drought, heat stress, and heavy insect herbivory constitute stresses where the effects of endophytes on plants often become apparent. In some instances, years may pass before significant benefits are noticed Therefore, it is understandable that some studies (20) may have failed to demonstrate endophyte-mediated improvements in disease suppression, since these grasses were not maintained in the field under the stresses of intensive turf management.

The fine fescues are outcrossing species showing high variation between and within natural populations. The E+ and E- entries that we have employed in these studies are not clones. Thus, host variation is expected to be a consideration in evaluating the source of suppression to dollar spot. However, many of the E+ and E- varieties share parental lines so they are closely related. Some E+ and E- cultivars, including SR 3000 and SR 5100, were developed from the same parental population by selecting for or against the endophyte; otherwise, the two breeding lines are genetically similar. Longfellow hard fescue was developed as a high endophyte containing variety, whereas Longfellow E- was selected from this variety after the loss of endophyte spot was observed (Tables 3 and 4). From 1991 to 1993 , turf quality ratings for E+ cultivars and selections within the hard and strong creeping red fescues were generally 
Table 4. Turf quality, foliar mycelia of Sclerotinia homoeocarpa, and dollar spot severity in Chewings and hard fescue cultivars (with and without endophyte) maintained under two nitrogen regimes in a field trial established September 1991 at Adelphia, NJ

\begin{tabular}{|c|c|c|c|c|c|c|}
\hline \multirow[b]{3}{*}{ Entryw } & \multirow[b]{3}{*}{ Endophyte $^{x}$} & \multirow{3}{*}{$\begin{array}{c}\text { Turf } \\
\text { quality }\end{array}$} & \multirow{3}{*}{$\begin{array}{c}\text { Foliar } \\
\text { mycelium }^{z}\end{array}$} & \multicolumn{3}{|c|}{ Disease severity $^{\mathrm{v}}$} \\
\hline & & & & \multicolumn{2}{|c|}{$\begin{array}{c}\text { Low } \\
\text { fertility }\end{array}$} & \multirow{2}{*}{$\begin{array}{c}\begin{array}{c}\text { High } \\
\text { fertility }\end{array} \\
10-7\end{array}$} \\
\hline & & & & $10-3$ & $10-7$ & \\
\hline \multicolumn{7}{|l|}{ Chewings fescue } \\
\hline Jamestown II ' $89 * *$ & E- & 5.6 & 9.7 & 11.4 & 16.3 & 2.0 \\
\hline Jamestown II '90** & E- & 5.6 & 8.7 & 9.9 & 15.6 & 1.5 \\
\hline Jamestown II '91** & $\mathrm{E}+$ & 5.2 & 1.4 & 0.6 & 0.3 & 0.1 \\
\hline $\operatorname{LSD}(P=0.05)$ & & 0.2 & 4.5 & 4.0 & 7.3 & 1.4 \\
\hline SR 5000 & $\mathrm{E}+$ & 6.2 & 0.0 & 0.3 & 0.3 & 0.0 \\
\hline SR 5000 & E- & 6.1 & 7.1 & 14.3 & 11.6 & 2.9 \\
\hline SR 5100 & $\mathrm{E}+$ & 6.4 & 0.0 & 0.1 & 0.1 & 0.0 \\
\hline SR 5100 & E- & 6.8 & 5.1 & 5.7 & 4.7 & 1.3 \\
\hline $\operatorname{LSD}(P=0.05)$ & & 0.3 & 3.9 & 5.8 & 4.4 & 1.4 \\
\hline \multicolumn{7}{|l|}{ Hard fescue } \\
\hline Reliant M801-CF8* & $\mathrm{E}+$ & 5.3 & 1.3 & 0.4 & 2.4 & 0.2 \\
\hline Reliant J09-1** & E- & 5.9 & 8.5 & 6.7 & 9.0 & 2.0 \\
\hline Reliant* & $\mathrm{E}+$ & 5.4 & 0.8 & 0.7 & 1.5 & 0.2 \\
\hline $\operatorname{LSD}(P=0.05)$ & & 0.3 & 2.6 & 3.4 & 3.3 & 1.1 \\
\hline SR 3000 & $E+$ & 6.3 & 0.3 & 1.3 & 0.6 & 0.0 \\
\hline SR 3000 & E- & 4.4 & 8.3 & 9.1 & 6.7 & 2.1 \\
\hline SR 3000 & E- & 4.1 & 8.3 & 8.6 & 5.9 & 1.9 \\
\hline SR 3100 & E- & 7.2 & 7.9 & 8.3 & 5.4 & 1.3 \\
\hline SR 3100 & $\mathrm{E}+$ & 7.4 & 0.0 & 0.4 & 0.1 & 0.0 \\
\hline $\operatorname{LSD}(P=0.05)$ & & 0.6 & 2.4 & 4.3 & 4.2 & 1.5 \\
\hline
\end{tabular}

${ }^{\mathrm{v}}$ Disease severity was assessed in 1992 as the percentage of turf area exhibiting foliar symptoms of dollar spot. Turf received $58.8 \mathrm{~kg} \mathrm{~N} \mathrm{ha}^{-1}$ from 15 April to 1 September 1992 . Plots were then equally split into high- and low-fertility subplots, and the high fertility half of each plot received an additional $46.5 \mathrm{~kg} \mathrm{~N} h a^{-1}$ on 2 September and 21 September 1992, respectively.

${ }^{\text {w }}$ Entries were replicated seven times unless identified by an $(n=10)$ or $(n=20)$.

x Endophyte status was determined microscopically by examining the leaf sheaths of 10 randomly selected tillers per entry stained with rose bengal. Endophyte-infected and endophyte-free entries are represented by E+ and E-, respectively.

y Turf quality was determined using a visual rating scale of 1 to 9 , where $9=$ the best quality turf. Values are annual means of multiple evaluations conducted throughout the 1992 growing season.

${ }^{\mathrm{z}}$ Represents a visual estimate of the percentage of turf foliage covered with the mycelium of $S$. homoeocarpa per plot on 28 September 1992.

viability during seed storage. Although the studies reported here involve diverse varieties and lineages of fine fescues obtained from throughout the United States and Europe, in every comparison to E- turf, the E+ turf showed suppression of dollar spot. It is also interesting to note the uniform abundance of dollar spot mycelium on Eplots compared with the near absence of mycelium on E+ plots, indicating that $E$. festucae was responsible for the disease suppression.

The mechanism of disease resistance in E+ fine fescues is not known and presumably is more complicated than insect resistance. It is widely accepted that alkaloids in E+ plants play a major role in either preventing insects from feeding on grass plants or have an antibiosis effect on the insect pest (9). The mechanism of disease resistance in $\mathrm{E}+$ plants may be due to the presence of similar or related endophyte-produced alkaloids, new compounds, or phytoalexins produced by plants in response to endophyte infection. Alternatively, Moy et al. (11) proposed that a network of epiphyllous mycelium on the surface of leaf blades of many infected fine fescues may exclude pathogens by preventing colonization of grasses by poten-
LITERATURE CITED

1. Blank, C. A., and Gwinn, K. D. 1992. Soilborne seedling diseases of tall fescue: Influence of the endophyte, Acremonium coenophialum. (Abstr.) Phytopathology 82: 1089.

2. Bonos, S. A., Wilson, M. M., Meyer, W. A., and Funk, C. R. 2005. Suppression of red thread in fine fescues through endophytemediated resistance. Applied Turfgrass Science. Online, publication DOI:10.1094/ATS2005-0725-01-RS.

3. Breen, J. P. 1993. Enhanced resistance to fall armyworm (Lepidoptera: Noctuidae) in Acremonium endophyte infected turfgrasses. J. Econ. Entomol. 86:621-629.

4. Clay, K. 1989. Clavicipitaceous endophytes of grasses: Their potential as biocontrol agents. Mycol. Res. 92:1-12.

5. Funk, C. R., Halisky, P. M., Ahmad, S., and Hurley, R. H. 1985. How endophytes modify turfgrass performance and response to insect pests in turfgrass breeding and evaluation trails. Pages 137-145 in: Proc. Int. Turf Res. Conf., 5th, Avignon, France. F. Lemaire, ed INRA Publications, Versailles, France.

6. Funk, C. R., White, R. H., and, Breen, J. P. 1992. Importance of Acremonium endophytes in turfgrass breeding and management. Pages 215-232 in: Proc. Int. Sympos. Acremonium/Grass Interact. R. E. Joost and S. S. Quisenberry, eds. Elsevier Science Publishers, Baton Rouge, LA.

7. Greulich, F., Horio, E., Shimanuki, T., and Yoshihara, T. 1999. Field results confirm natural plant protection by the endophytic fungus Epichlö typhina against the pathogenic fungus Cladosporium phlei on timothy leaves. Ann. Phytopathol. Soc. Jpn. 65:454459.

8. Gwinn, K. D., and Gavin, A. M. 1992. Relationship between endophyte infestation level of tall fescue seed lots and Rhizoctonia zeae seedling disease. Plant Dis. 76:911-914.

9. Hill, N. S., Parrott, W. A., and Pope, D. D 1991. Ergopeptine alkaloid production by endophytes in a common tall fescue genotype. Crop Sci. 31:1545-1547.

10. Lyons, P. C., Plattner, R. D., and Bacon, C. W. 1986. Occurrence of peptide and clavine ergot alkaloids in tall fescue grass. Science 232:487489. ryegrasses possessing the endophyte $\mathrm{NeO}$ typhodium lolii do not have a comparable epiphyllous stage, and dollar spot suppression was not observed in numerous field trials of $\mathrm{E}+$ and E- perennial ryegrass at our Adelphia research station. To further evaluate endophyte-enhanced disease suppression, we plan to continue observations on grasses with respect to disease incidence and the presence of endophytes in various grass species. We also intend to evaluate the mechanism of enhanced resistance to fungal pathogens so that endophytes may be screened in vitro for their ability to suppress turfgrass diseases. Endophyte strains that show strong disease-suppressive potential will then be used in our turfgrass breeding program to improve turfgrass performance in the field.

\section{ACKNOWLEDGMENTS}

We thank Ron Bara, Lora Betts, and Dirk Smith for their technical assistance and suggestions. This study was supported by the New Jersey Agricultural Experiment Station, the Rutgers Center for Turfgrass Science, the United States Golf Association, the Golf Course Superintendents Association of America, and the New Jersey Turfgrass Association.
11. Moy, M. H., Belanger, F. C., Duncan, R., Frehoff, A., Leary, C., Meyer, W., Sullivan, R., and White, J. F. 2000. Identification of epiphyllous mycelial nets on leaves of grasses infected by clavicipitaceous endophytes. Symbiosis 28:291-302.

12. Saha, D. C., Jackson, M. A., and JohnsonCicalese, J. M. 1988. A rapid staining method for detection of endophytic fungi in turf and forage grasses. Phytopathology 78:237-239.

13. Saha, D. C., Johnson-Cicalese, J. M., Halisky, P. M., Van Heemstra, M. I., and Funk, C. R. 1987. Occurrence and significance of endophytic fungi in the fine fescues. Plant Dis. 71:1021-1024.

14. Sampson, K. 1933. The systemic infection of grasses by Epichloë typhina (Pers.) Tul. Trans. Br. Mycol. Soc. 18:30-47.

15. Schmidt, D. 1990. Antagonistic effect of Acremonium spp. against potential pathogens. Pages 52-57 in: Proc. Int. Sympos. Acremonium/Grass Interact. S. S. Quisenberry and R. E. Joost, eds. Louisiana Agric. Exp. Stn., Baton Rouge.

16. Siegel, M. R., Latch, G. C. M., and Johnson, M. R. 1987. Fungal endophytes of grasses. Annu. Rev. Phytopathol. 25:293-315.

17. Smith, J. D., Jackson, N., and Woolhouse, A. R. 1989. Fungal diseases of amenity turf grasses. 3rd ed. E. and F. N. Spon., New York. Effects of fertilizer and fungicide applications
18. Sun, S., Clarke, B. B., and Funk, C. R. 1990. 
on choke expression and endophyte transmission in Chewings fescue. Pages 62-66 in: Proc. Int. Sympos. Acremonium/Grass Interact. S. S. Quisenberry and R. E. Joost, eds. Louisiana Agric. Exp. Stn., Baton Rouge.

19. Tajimi, A. 1990. Useful and harmful effects of endophyte in timothy (Phleum pratense L.). Annu. Rep. Kokido Agric. Exp. Stn. 34:8-11.
20. Welty, R. E., Barker, R. E., and Azevedo, M. D. 1991. Reaction of tall fescue infected and noninfected by Acremonium coenophialum to Puccinia graminis subsp. graminicola. Plant Dis. 75:883-886.

21. West, C. P., Oosterhuis, D. M., and Wullschleger, S. D. 1990. Osmotic adjustment in tissues of tall fescue in response to water defi- cit. Environ. Exp. Bot. 30:149-156.

22. White, J. F., Jr. 1987. The widespread distribution of endophytes in the Poaceae. Plant Dis. 71:340-342.

23. White, J. F., Jr., and Cole, G. T. 1985. Endophyte-host associations in forage grasses. III In vitro inhibition of fungi by Acremonium coenophialum. Mycologia 77:487-489. 